\title{
CONDITIONING METHODS FOR ANIMALS IN AGRICULTURE: A REVIEW
}

\section{MÉTODOS DE CONDICIONAMENTO PARA ANIMAIS EM AGRICULTURA: UMA REVISÃO}

\author{
Charles Ira Abramson ${ }^{1 *}$ \\ Emily Kieson ${ }^{1}$
}

'Laboratory of Comparative Psychology and Behavioral Biology, Departments of Integrative Biology and
Psychology, Oklahoma State University, Stillwater, OK, USA.
"Corresponding author - charles.abramson@okstate.edu.

\begin{abstract}
This article briefly describes different conditioning techniques used to help understand learning in farm livestock and economically important animals. A basic overview of conditioning is included along with the importance of different conditioning methods, associative and non-associative learning, and how these principles apply to chickens, horses, cows, goats, pigs, and sheep. Additional information on learning theory specific for each animal is also provided.
\end{abstract}

Keywords: cattle; classical; conditioning; goats; horses; operant; pigs; sheep; training.

\section{Resumo}

Este artigo descreve brevemente diferentes técnicas de condicionamento usadas para ajudar a compreender a aprendizagem em animas de criação e animais economicamente importantes. Uma visão geral básica de condicionamento está incluída juntamente com a importância de diferentes métodos de condicionamento, aprendizagens associativas e não-associativas e como esses princípios se aplicam para as galinhas, cavalos, vacas, suínos, caprinos e ovinos. Informações adicionais sobre a teoria de aprendizagem específica para cada animal também são fornecidas.

Palavras-chave: bovinos; caprinos; cavalos; clássico; condicionamento; operante; ovinos; suínos; treinamento.

Received on: June, $15^{\text {th }}, 2016$

Accepted on: June, 20 2016

\section{Introduction}

The senior author has been conducting research on animal behavior in Brazil since the late 1990s. During this time he has had the opportunity to interact with many Brazilian researchers interested in the behavior of farm animals. As a result of these interactions, it became apparent that there is the need for a brief review of conditioning methods and how they can be applied to better the lives of farm animals. A second rationale for this article is that we believe that the information we provide can be used to educate local farmers and ranchers regarding the many advantages of applying conditioning methods. A thorough understanding of species-specific behavior and their ability to be conditioned through traditional methods can improve safety, efficiency, and production in each industry. 
Animal learning theory and conditioning methods are important to agricultural and farming industries in order to facilitate improvements in both animal welfare and human safety. For example, the use of appropriate habituation techniques can help animals transition into novel environments and reduce stress associated with new management techniques, exposure to novel equipment, husbandry procedures, or human strangers ${ }^{(1)}$. Furthermore, these same conditioning techniques can be used to help farmers and veterinarians better handle large animals during medical procedures such as palpations, examinations, husbandry, breeding, and vaccinations.

Conditioning techniques can also be used to help animals adjust to regular maintenance such as grooming, milk or fur collection procedures, hoof trimming, and weight data collection. In addition to management procedures, a more thorough understanding of livestock, their domestication, learning theory, and conditioning can also help with the development of environmental enrichment products for both working and agricultural animals ${ }^{(2,3)}$. With regards to the concepts of conditioning, research in comparative psychology helps with assessing the similarities and differences between species and parallels in learning theory can assist with creating new understanding of how farm animals adapt and learn in new environments ${ }^{(4)}$.

The purpose of conditioning methods is to help develop theories of how animals learn. A second, equally important purpose, is to develop a class of techniques that can be used in an applied setting. In comparative psychology, learning is defined as a relatively permanent change in behavior that results from experience ${ }^{(5)}$. In order to better understand the process of learning, comparative and animal behavioral psychologists have created two categories of learning: Associative and Non-Associative. Associative learning is when an organism learns a behavior based on the association of two or more events. Both classical and operant conditioning are considered associative learning processes and it is under these conditions that the animal may learn a new response. Non-associative learning, on the other hand, is a more basic learning process in which a behavior is changed in response to an event or stimulus that is repeatedly presented. In this case, the animal does not learn a new behavior, but instead learns to modify an existing behavior based on a change in environment or stimulus. This type of learning is considered more fundamental for behavioral modification and is most commonly seen through the processes of sensitization and habituation.

\section{A Brief Overview of Conditioning Methods}

In this section we will present a brief overview of non-associative and associative learning. NonAssociative learning is broken into sections on habituation and sensitization to help readers understand the basic principles behind these concepts and techniques. Further information for each concept will be described in the sections devoted to each livestock species. Associative learning is comprised of a section on classical conditioning and a section on operant conditioning. Again, the use of each concept for a given animal is described in the livestock sections.

\section{Non-Associative Learning}

\section{Habituation}

Non-associative learning is most commonly used with regards to techniques in sensitization and habituation. Habituation refers to the reduction of a response to a repeated stimulus and includes some of the following characteristics ${ }^{(6)}$ :

1. Habituation happens faster when the stimulus is repeated more rapidly.

2. Habituation is slow when the stimulus is weak.

3. Generalization can occur when habituation to one stimulus creates habituation to similar stimulus.

4. Spontaneous recovery occurs when the stimulus is withheld for a prolonged period of time which results in the recovery of the initial response.

5. The rate of habituation increases as the frequency of training increases.

6. Dishabituation may occur if the stimulus is too strong (too much or too fast) resulting in the return of the original response. 
7. Habituation of dishabituation can result with the continued application of the dishabituation.

\section{Sensitization}

Sensitization is essentially the opposite of habituation since it refers to the increase in frequency or probability of a behavioral response to a given stimulus. Characteristics of sensitization include:

1. The probability of sensitization increases as the strength of stimulus increases.

2. Generalization can occur when the sensitization of one stimulus results in the same response to similar stimuli.

\section{Repeating exposure to the sensitized stimulus may result in desensitization.}

The study of habituation and sensitization are enormously important to the agriculture and farming industries. Both principles share properties with more complex learning theories which can result in improved performance and reduced stress in agricultural animals and livestock. Research on habituation and sensitization across species has resulted in hundreds of studies demonstrating the importance of habituation and sensitization in working animals, farm animals, and traditional livestock. Although these two principals are typically seen as basic phenomena in learning, they are two of the most important concepts in agriculture due to their adaptive value and the behavioral changes that occur are just as important as those seen in classical or operant conditioning. The paper by Abramson ${ }^{(7)}$ describes basic non-associative learning experiments that can be adapted to livestock.

\section{Associative Learning}

\section{Classical Conditioning}

Classical conditioning refers to behavioral modification that results from the pairing of a neutral/ conditioned stimulus (CS) with a known second/unconditioned stimulus (US) that has a previously known/unconditioned response (UR). When done correctly, this pairing results in the CS eliciting the same response (UR) as the original unconditioned stimulus (US) without the presence of the US. This new response to the CS without the US is known as the conditioned response (CR). This is an example of associative learning where a behavior results from the pairing of two or more stimuli and results in the biological reflex originally initiated by the CS and is seen as one of the most basic associative learning mechanisms ${ }^{(8)}$. Characteristics of classical conditioning include:

1. Intensity of the CS is positively related to the effectiveness of the training. However, a CS that is too intense will not be effective.

2. Intensity of the US is positively related to the effectiveness of the training. However, a US that is too intense will not be effective.

3. When paired, the time between the CS and US is important: the shorter the interval, the more effective the training. The CS-US interval should not be " 0 ".

4. Frequency of pairing between CS and US is positively related to the effectiveness of the training.

5. If CS and US become unpaired, the response to the US gradually disappears.

6. If a response has been established with a CS, similar stimuli may elicit the same response.

\section{Operant Conditioning}

Operant conditioning occurs when behaviors are modified or changed when the consequences for that behavior are changed. In this sense, behaviors can be reinforced or punished. Behaviors that are reinforced are more likely to occur while those that are punished are less likely to occur. Both reinforcement and punishment can be positive or negative with positive referring to the addition of a stimulus and negative referring to the removal of a stimulus. With regards to positive reinforcement, many animals respond to reward training (positive reinforcement) with the use of food or other rewarding stimuli as a means of linking a given behavior to a specific reward. This type of reinforcement can be especially important when considering animal behavior with regards to specific people or procedures. Animals use associative learning when pairing undesirable events with other environmental factors. For example, many livestock have aversive reactions to the veterinarian since they associate the pain 
or discomfort of a procedure with a given person or place. This then results in the animal exhibiting fear or undesirable behavior without the veterinarian present if the paired stimulus is present. If the animal is able to avoid the fearful or painful stimulus through the use of a given behavior, the animal then learns to repeat that behavior under those circumstances. The repetition of such behavior can be considered negative reinforcement since the behavior is reinforced through the removal (in this case avoidance) of an unwanted or unpleasant stimulus. If positive reinforcement is introduced, however, the animal can learn to associate the act of standing, picking up feet, basic calm behavior with a reward (usually food) and will then repeat a more desired behavior under the same circumstance.

With regards to punishment training, however, stimuli are added (positive punishment) or taken away (negative punishment) in order to decrease the likelihood of a behavior being repeated. In this instance, an animal may be punished for a specific behavior through the addition of an undesirable stimulus (positive punishment).

Both reinforcement and punishment are considered phenomena under operant conditioning which is a form of associative learning and is considered more complex than classical conditioning. Classical conditioning generally refers to how an animal pairs environmental stimuli with one biological response whereas operant conditioning refers to behavioral modifications that result from changes in consequences that result from chosen behaviors. Although they differ in many ways, classical and operant conditioning share concepts of generalization and discrimination (the ability to distinguish one stimulus from a similar one) as well as extinction and spontaneous recovery. Characteristics of operant conditioning include ${ }^{(9)}$ :

1. Reward quality and value is positively related to the rate of behavioral acquisition

2. Timing between response and reward is important: The greater the time, the slower the behavioral acquisition

3. Motivation of the animal is positively related to the rate and frequency of response (motivation and reward value are highly correlated)

4. If the reward is no longer administered, the response will generally decrease and stop over time.

\section{Environmental Enrichment}

Environmental enrichment is considered to be a practice that increases the physiological and psychological wellbeing of animals through increases and changes in environmental stimulation ${ }^{(10)}$. It has been used to reinforce behavioral training, but is most often used as a means of increasing animal welfare for both domestic and captive species. With regards to animals in captivity or in environmental conditions that greatly differ from natural environments, environmental enrichment is employed to decrease stereotypies or behavioral "vices". Such behaviors usually manifest as repetitive actions and behaviors that result from an environment lacking in species-specific stimulus ${ }^{(11)}$. For example, stabled horses may exhibit stall weaving or wood chewing due to lack of opportunities for movement or foraging ${ }^{(12,13)}$, which can often result in decreased physical and psychological wellness ${ }^{(14)}$. Providing greater opportunities to walk, longer grazing time, and constant visual access to other horses can often decrease such behaviors. Although some behaviors are learned through operant conditioning, many of these stereotypies result from a behavioral need of the individual that is not being met by current environmental conditions. Therefore, when considering environmental enrichment, it is important to acknowledge the species-specific needs of the individual and the potential reasons behind the unwanted behavior prior to utilizing environmentally enriching devices or plans.

In order to provide appropriate environmental enrichment, caretakers must consider the specific needs of the species. Much like horses who need to walk or see other conspecifics to reduce stall weaving and decrease stress, chickens may make use of containers of dirt for use as dust baths which reduces feather plucking and other indicators of stress. In order for environmental enrichment stimuli to be effective, however, caretakers need to consider the potential habituation to the naturally reinforcing stimulus $^{(2)}$. In this case, animals may make use of environmental enrichment until the effect is no longer rewarding at which point the animal may become habituated to the stimulus ${ }^{(2)}$. This can be avoided, however, through the careful consideration of the properties of habituation ${ }^{(8)}$. 
In addition to physical changes in living areas, environmental enrichment can also be created through positive and extrinsic reinforcement. Food, for example, can be used to reinforce healthy behaviors and assist in shaping animal behaviors that increase welfare. Failure to provide appropriate reinforcement, however, may result in extinction of the desired behavior (extinction). In order to avoid this, it is important to provide intermittent reinforcement. Again, a thorough understanding of species' needs is critical in creating an environment that both increases the behavioral needs of the individual and provides appropriate stimulus to reinforce desired behaviors.

\section{Conditioning with Regards to Specific Species of Interest to Brazilian Agriculture and Veterinarians}

Much like environmental enrichment, conditioning methods also need to be tailored to individuals and species. Here we address some of the common livestock that veterinarians in Brazil regularly encounter. In order to assist readers with finding additional information, tables have been provided to guide individuals to other sources of interest.

\section{Chickens}

Chickens are a common species of livestock for both small and large farmers, which creates many opportunities to research their needs and preferences in order to facilitate optimal welfare. Since high stress often results in low productivity, determining optimal environments for chickens at the lowest cost will benefit both animal and farmer. In this case, chickens trained to push levers to change cage sizes have shown that their preferred cage size is about $632 \mathrm{~cm}^{2}$ for each bird ${ }^{(15)}$. This was below the available maximum cage size and shows that a small, yet manageable habitat can increase bird welfare while still maintaining profitability.

Furthermore, with regards to environmental enrichment, other studies indicate that chickens exhibit signs of higher learning capabilities ${ }^{(16)}$ and species-specific behaviors that may indicate their emotional state $^{(17)}$. When a positive reinforcement was removed from a behavioral experiment, different breeds of hens displayed changes in specific vocal behaviors. In addition, another study used operant conditioning to teach young chicks to make specific vocal sounds in response to a positive food reinforcement ${ }^{(18)}$. The chicks were able to control their vocalizations and learn to create specific sounds to gain food, indicating that chicks and chickens can control and use their vocalizations. As a result, researchers determined that changes in these vocal behaviors may be used as a good indicator of stress in these breeds, further supporting research suggesting that animal behavioral psychology contributes to animal welfare ${ }^{(19)}$. It is also known that domestic chickens exhibit complex learning, intricate social behavior, and possess a remarkable memory ${ }^{(20,21)}$. Table 1 provides some additional resources in chicken learning and conditioning.

Table 1. Conditioning Research in Chickens

\begin{tabular}{lll}
\hline Authors & Year & Title \\
\hline Lane $^{(18)}$ & 1961 & $\begin{array}{l}\text { Operant control of vocalizing in the chicken } \\
\text { Operant conditioning and use of space by caged } \\
\text { laying hens }\end{array}$ \\
$\begin{array}{l}\text { Zimmerman } \\
\text { Koene }\end{array}$ & \& 1988 \\
Smith \& Johnson & 1998 & $\begin{array}{l}\text { The effect of frustrative nonreward on vocalizations } \\
\text { and behavior in the laying hen, Gallus gallus } \\
\text { domesticus } \\
\text { The Chicken Challenge: What Contemporary Studies } \\
\text { of Fowl Mean for Science and Ethics }\end{array}$ \\
\hline
\end{tabular}




\section{Cows}

Cows are one of the largest livestock that has been domesticated for both meat and dairy. In order to provide additional resources for individuals looking to learn more about cows and cattle, Table 2 has been added as a source of articles on conditioning methods for cows.

Table 2. Conditioning Research in Cows

\begin{tabular}{|c|c|c|}
\hline Authors & Year & Title \\
\hline $\begin{array}{l}\text { Dabrowska, Harmata, } \\
\text { Lenkiewicz, Schiffer \& } \\
\text { Wojtusiak }^{(22)}\end{array}$ & 1981 & Colour perceptions in cows \\
\hline $\begin{array}{l}\text { Foster, } \\
\text { Robtertson, Nemple, } \\
\text { Poling }{ }^{(23)}\end{array}$ & 1996 & $\begin{array}{l}\text { Concurrent-schedule performance in dairy cows: } \\
\text { Persistent undermatching }\end{array}$ \\
\hline Matthews \& Temple ${ }^{(24)}$ & 1996 & $\begin{array}{l}\text { Concurrent schedule assessment of food preferences } \\
\text { in cows }\end{array}$ \\
\hline $\begin{array}{l}\text { Pajor, Rushen \& de } \\
\text { Passilé(25) }\end{array}$ & 2000 & $\begin{array}{l}\text { Aversion learning techniques to evaluate dairy cattle } \\
\text { handling practices }\end{array}$ \\
\hline $\begin{array}{l}\text { Rybarczyk, Koba, } \\
\text { Rushen, Tanida \& de } \\
\text { Passillé(26) }\end{array}$ & 2001 & Can cows discriminate people by their faces? \\
\hline $\begin{array}{l}\text { Arnold, Ng, Jongman \& } \\
\text { Hemsworth }\end{array}$ & 2008 & $\begin{array}{l}\text { Avoidance of tape-recorded milking facility noise by } \\
\text { dairy heifers in a Y maze choice task }\end{array}$ \\
\hline $\begin{array}{l}\text { Lee, Henshall, Wark, } \\
\text { Crossman, Reed, } \\
\text { Brewer, O'Grady \& } \\
\text { Fisher }^{(28)}\end{array}$ & 2009 & $\begin{array}{l}\text { Associative learning by cattle to enable effective and } \\
\text { ethical virtual fences }\end{array}$ \\
\hline
\end{tabular}

Cows are often herded and forced through shoots for collection of milk or for veterinary procedures which often involves the use of aversive learning such as punishment and escape ${ }^{(29)}$. The observation of confusion or fear behavior under these conditions has been used to compare handling techniques and animal welfare. In order to determine whether the handling technique was aversive or pleasurable, one study used a "race" that walked cows down a stretch (raceway) at the end of which they were exposed to a specific aversive or potentially pleasurable stimulus ${ }^{(25)}$. After a series of trials, if the cows walked faster, the stimulus was seen as pleasurable, but if the cow avoided walking, then the stimulus was considered aversive. Researchers found that cattle were more willing to move when presented with positive reinforcement (food) rather than aversively motivated through the use of negative reinforcement (cattle prods, yelling, hitting). This suggests that using food to assist in moving cattle through shoots or herds may be more beneficial and efficient than methods that use aversive stimuli.

Another study looked at dairy cattle response to typical sounds in a milking facility and found that cows given a choice of whether to move towards those sounds versus neutral stimuli preferred to avoid the milking noises ${ }^{(27)}$. Much like the race, this study indicates the ability to assess cow preferences in a wide range of environments. Furthermore, when behavioral needs such as feeding and rest were taken into consideration, another study found that cows exhibited less stress and produced more milk 
when given ample time to eat and sleep ${ }^{(30)}$. Behavioral needs such as these need to be considered when determining proper management techniques in order to ensure animal welfare and maximum production.

Furthermore, cows have the ability to distinguish between people ${ }^{(26)}$ when exposed to an operant learning environment in which the cows pressed levers in front of individuals who were either specified as a rewarder (giving food reward) or non-rewarder (no reward). The experiment showed that cows used multiple visual cues to distinguish between people, which can indicate that their behavioral changes around people may be indicative of their associative learning with regards to specific individuals.

With regards to herd management in fields or on large farms, operant learning has been shown to be of value when teaching cattle to remain contained when using virtual fences in the same manner with which they regard conventional electric fences ${ }^{(28)}$. An audible signal was used in conjunction with a small harmless (yet aversive) shock to help teach cows to stay within certain boundaries. The researchers found that if the sound was used in conjunction with the aversive stimuli, the cows learned to contain themselves within the virtual fence, even if the boundaries changed.

Operant conditioning in cattle has also been used to determine color discrimination and food preferences. One study used large color and grey cards to determine color discrimination where cows were only given a food reward for choosing the colored card ${ }^{(22)}$. The study results strongly indicated that cows can distinguish color. Further use of operant conditioning was seen in a study that determined cow food preferences where cows were given a choice between food reinforcement opportunities $^{(23,24)}$. The results of the study indicated that cows preferred crushed barley to meatmeal showing that operant conditioning and positive reinforcement can be used to learn more about cattle preferences, learning, and discrimination. Food and reward preferences can be used to improve positive reinforcement training such as one used to facilitate behavioral changes in voluntary milking facilities $^{(31)}$.

Further studies indicate that a careful assessment of cow behavior and welfare can aid in management and overall safety considerations for both livestock and humans ${ }^{(32)}$. For example, tests in weaning determined that there were higher stress levels when calves were separated at much younger ages than those separated from their mothers at older stages ${ }^{(33)}$.

\section{Horses}

Horses are used around the world for both work and recreation and a large number of studies have been done to explore discrimination and learning in different environments. Horses tend to be easy to study because even well-fed horses respond well to food reinforcement and studies indicate that horses can discriminate between people, shapes ${ }^{(34)}$, and colors ${ }^{(35)}$. Furthermore, horses show response matching ${ }^{(36)}$, some degree of stimulus generalization ${ }^{(37)}$, respond to different reinforcement schedules $^{(38)}$ and differential rewards ${ }^{(39)}$. Moreover, horses have impressive ability to time rewarding events $^{(40)}$. In one study, horses were trained to respond to a stimulus and tested to determine how quickly they learned to adjust if the reward was reversed (the reward was removed from the initial stimulus and associated with a previous neutral stimulus). This study used both lights and objects as conditioned stimulus and suggested that horses learned better from object discrimination rather than light stimulus ${ }^{(41)}$.

Additional studies have shown that horses can learn and perform more complex tasks beyond just discrimination ${ }^{(38,42)}$. Studies have shown they can differentiate between shapes and sizes as well as respond to tasks that involve choices and matching. Historically, horses have been trained through primarily negative reinforcement techniques, but there is growing evidence to suggest that positive reinforcement training programs may be better suited to training horses ${ }^{(43-45)}$. Table 3 provides a list of additional resources for professionals looking at conditioning in horses. 
Table 3. Conditioning Research in Horses

\begin{tabular}{|c|c|c|}
\hline Authors & Year & Title \\
\hline Myers \& Mesker ${ }^{(38)}$ & 1960 & $\begin{array}{l}\text { Operant responding in a horse under several } \\
\text { schedules of reinforcement }\end{array}$ \\
\hline Dougherty \& Lewis ${ }^{(35)}$ & 1992 & $\begin{array}{l}\text { Stimulus generalization, discrimination learning, and } \\
\text { peak shift in horses }\end{array}$ \\
\hline Dougherty \& Lewis ${ }^{(36)}$ & 1992 & $\begin{array}{l}\text { Matching by horses on several concurrent variable- } \\
\text { interval schedules }\end{array}$ \\
\hline Dougherty \& Lewis ${ }^{(37)}$ & 1993 & Generalization of a tactile stimulus in horses \\
\hline $\begin{array}{l}\text { Miyashita, Nakajima \& } \\
\text { Imada }{ }^{(39)}\end{array}$ & 2000 & Differential outcome effect in the horse. \\
\hline $\begin{array}{l}\text { Ferguson \& Rosales- } \\
\text { Ruiz }^{(43)}\end{array}$ & 2001 & $\begin{array}{l}\text { Loading the problem loader: The effects of target } \\
\text { training and shaping on trailer-loading behavior of } \\
\text { horses }\end{array}$ \\
\hline Hanggi $i^{(34)}$ & 2003 & $\begin{array}{l}\text { Discrimination learning based in relative size } \\
\text { concepts in horses (Equus caballus) }\end{array}$ \\
\hline $\begin{array}{l}\text { Martin, Zentall } \\
\text { Lawrence }^{(39)}\end{array}$ & 2006 & $\begin{array}{l}\text { Simple discrimination reversals in the domestic horse } \\
\text { (Equus caballus): Effect of discriminative stimulus } \\
\text { modality on learning to learn. }\end{array}$ \\
\hline Gabor \& Gerken ${ }^{(36)}$ & 2012 & $\begin{array}{l}\text { Cognitive testing in horses using a computer based } \\
\text { apparatus }\end{array}$ \\
\hline
\end{tabular}

Unlike other livestock, horses are unique in their place in agriculture since they are primarily used as work animals as opposed to being used as food sources. In this regard, training and conditioning of horses can often be even more important since their training is of primary importance with those who utilize them for work. With this in mind, new studies have emerged that suggest the importance of positive reinforcement training in horses and a better understanding of how learning theory and operant conditioning applies to equines ${ }^{(46,47)}$.

\section{Goats and Sheep}

Goats and sheep are much smaller agricultural herd animals than cattle and can be kept in smaller areas due to their manageable size. Much like cattle, sheep and goats are versatile livestock and are raised for both meat and dairy products. In order to facilitate greater access to conditioning in goats and sheep, Table 4 has been provided as a list of resources in this area.

With regards to conditioning and learning in goats, one experiment suggested that goats may find value in learning and environmental enrichment ${ }^{(50)}$. In this experiment, researchers trained goats to interact with a learning device in exchange for a small amount of water. Once the goats were trained, the same device was incorporated into an environment with an additional small lever (which the goats also learned to use) that dispensed the same amount of water. Even with both devices, some goats still used the learning device to gain water, indicating that the goats found some value in using the device.

Furthermore, conditioning in sheep and goats is used when attempting to create an aversive reaction to a given food or plant. In many cases, farmers hope to train their sheep and goats to avoid specific toxic plants by creating a conditioned food aversion by pairing a food with an aversive (usually illness-inducing) stimulus. The idea is to create an association between the food and the illness which results in the animals' aversion of the food. In one study attempting to train sheep not to consume a toxic plant, researchers used the food aversion technique, but only found that non-lethal doses 
of the plant itself resulted in sheep avoidance of the actual plant ${ }^{(51)}$. The same technique was also attempted in hopes of preventing goats and sheep from consuming olive trees ${ }^{(52)}$. In this instance, the researchers provided animals with olive leaves followed by an illness-inducing substance in hopes of creating an association. The study indicated that the pairing of the substance with the olive leaves succeeded in creating an aversion to olive trees.

Table 4. Conditioning Research in Goats and Sheep

\begin{tabular}{|c|c|c|}
\hline Authors & Year & Title \\
\hline $\begin{array}{l}\text { Wenzel, Baldwin, \& } \\
\text { Tschirgi }{ }^{(48)}\end{array}$ & 1964 & Operant conditioning of goats \\
\hline $\begin{array}{l}\text { Foster, Matthews, } \\
\text { Temple \& Poling } \\
\text { (49) }\end{array}$ & 1997 & $\begin{array}{l}\text { Concurrent schedule performance in domestic goats: } \\
\text { persistent undermatching }\end{array}$ \\
\hline $\begin{array}{l}\text { Langbein, Seibert \& } \\
\text { Nurnberg }{ }^{(50)}\end{array}$ & 2009 & $\begin{array}{l}\text { On the use of automated learning device by group- } \\
\text { housed dwarf goats: Do goats seek cognitive } \\
\text { challenges }\end{array}$ \\
\hline $\begin{array}{l}\text { de Almedia, Schild, } \\
\text { Brasil, Quevedo, Fiss, } \\
\text { Pfister \& Riet-Correa }{ }^{(51)}\end{array}$ & 2009 & $\begin{array}{l}\text { Conditioned aversion in sheep induced by Baccharis } \\
\text { coridifolia }\end{array}$ \\
\hline $\begin{array}{l}\text { Manielian, Albenell, } \\
\text { Salama \& Caja }{ }^{(52)}\end{array}$ & 2010 & $\begin{array}{l}\text { Conditioned aversion to olive tree leaves (Olea } \\
\text { europaea L.) in goats and sheep }\end{array}$ \\
\hline
\end{tabular}

In addition to traditional livestock research, scientists have also used goats in more experimental learning studies. One study by Wenzel, Baldwin, and Tschirgi ${ }^{(48)}$ studied basic operant conditioning in goats and found that goats showed the same basic response to conditioning techniques as other common laboratory animals. Unlike traditional laboratory animals, however, goats do not need to be food deprived to be motivated by food rewards which makes them easy to use in experiments and more suitable for more complex learning studies ${ }^{(50)}$.

\section{Pigs}

Although pigs are not found in as high numbers as cattle, they are still a major livestock in Brazil. Management of pigs is greatly influenced by their ability to learn about their environment, habituation to humans and techniques, and exposure to conspecifics. Resources are available in Table 5.

Perception of pigs in different cultures affects how societies manage and house them ${ }^{(57)}$ but despite these differences, pig learning and conditioning can affect efficient management practices, welfare, and production quality. There is evidence to suggest that pigs have the ability to learn from human cues as well as from conspecific social cues, especially when they have had the opportunity to learn from similar environments in the past ${ }^{(58)}$. This is especially important since studies show that desensitization and habituation to humans and different handling measures can help increase adaptation to different handling techniques (such as veterinary) and improve safety as well as decrease stress in the pig ${ }^{(59)}$. Done early enough during their growing stage, pigs that have been habituated and desensitized to humans and environments have a greater ability to adapt later, show decreased signs of stress, and show greater weight gains than pigs that have not been habituated ${ }^{(53)}$. On the other hand, stressful experiences with humans can influence a pig's ability to learn new or more complex tasks ${ }^{(54)}$, which can impact future habituation and training. Furthermore, stress in pigs has been shown to influence food consumption in pigs which would further influence their production of meat ${ }^{(60)}$. This means that managers and handlers need to consider basic concepts of conditioning when handling pigs of all ages and should consider starting conditioning practices during the growing stages of pigs in order to improve performance, production, and safety when the pig ages. 
Table 5. Conditioning Research in Pigs

\begin{tabular}{|c|c|c|}
\hline Authors & Year & Title \\
\hline de Oliveira D, Paranhos & & \\
\hline $\begin{array}{l}\text { da Costa MJR, Zupan } \\
\text { M, Rehn } T \text {, Keeling } \\
\text { LJ }^{(53)}\end{array}$ & 2015 & $\begin{array}{l}\text { Early human handling in non-weaned piglets: Effects } \\
\text { on behaviour and body weight }\end{array}$ \\
\hline Brajon S, Laforest J-P, & & A preliminary study of the effects of individual \\
\hline $\begin{array}{l}\text { Schmitt } \quad \mathrm{O}, \text { Devillers } \\
\mathrm{N}^{(54)}\end{array}$ & 2016 & $\begin{array}{l}\text { response to challenge tests and stress induced by } \\
\text { humans on learning performance of weaned piglets }\end{array}$ \\
\hline $\begin{array}{l}\text { van Eck LM, Antonides } \\
\text { A, Nordquist RE, van } \\
\text { der Staay } \mathrm{FJ}^{(55)}\end{array}$ & 2016 & $\begin{array}{l}\text { Testing post-weaning food motivation in low and } \\
\text { normal birth weight pigs in a runway and operant } \\
\text { conditioning task }\end{array}$ \\
\hline $\begin{array}{l}\text { Cornale } P, \text { Macchi E, } \\
\text { Miretti S, Renna M, } \\
\text { Lussiana C, Perona G, } \\
\text { et al }{ }^{(56)}\end{array}$ & 2009 & $\begin{array}{l}\text { Effects of stocking density and environmental } \\
\text { enrichment on behavior and fecal corticosteroid } \\
\text { levels of pigs under commercial farm conditions }\end{array}$ \\
\hline
\end{tabular}

Social dynamics also play a role in pig learning and behavior and managers also need to take this into consideration when understanding the role of conditioning in swine management. A better understanding of pig social structure and the natural behavioral cycles of pigs can increase welfare and production since pigs are often subject to rehousing situations ${ }^{(61)}$. For example, pigs, unlike other livestock, do not rely solely on visual stimulus for identifying conspecifics which can alter how handlers view the learning environments of their pigs and how to manage their environments ${ }^{(62)}$. Furthermore, another study exposed piglets to a situation in which they could either observe or participate with a sow while she was eating. Compared to the controlled piglets, those given an opportunity to learn through either watching or feeding with the sow were able to learn to eat faster from a feeder, suggesting that the social cues are important for feeding ${ }^{(60,63,64)}$, which can potentially influence the management and housing conditions for pigs. This is important since pigs retain memories of performance tasks which can influence future performances and learning ${ }^{(65)}$.

With regards to environmental enrichment in pigs, studies show that straw can improve pig welfare by providing a tool for exploratory behavior, especially during the growing period ${ }^{(66,67)}$. Mirrors have also been used with pigs as a means of enrichment and learning and have been shown to indicate assessment awareness, which could also lead to improved housing conditions and welfare for pig production facilities ${ }^{(68)}$. Although environmental enrichment may help with pigs and reduce stress (and consequently improve production), studies indicate that overall conditions, such as stocking density, needs to be considered in order to properly manage pig welfare ${ }^{(56,69)}$.

Breed and potential litter size can also affect learning ${ }^{(70)}$ as well as individual genetics ${ }^{(71)}$, which means that individual differences need to be taken into account when understanding habituation and learning in pigs. Pigs tested with food rewards in two operant conditioning tasks helped support the idea that food can be used as a motivator in learning behaviors ${ }^{(5)}$, which suggests that handlers and managers can use food as a reward in positive reinforcement training and to assist with habituation to humans and handling. This further supports the idea that a better understanding of how learning and habituation affects behavior can help managers develop better practices for developing safer, less stressful management techniques and provide for better observation practices dedicated to detecting early stages of stress or disease ${ }^{(72)}$. Further developments in science will also help improve researchers' abilities to determine links between biological measures and pig behavior which will 
help improve the understanding of pigs and increase welfare and production through the development of better management practices ${ }^{(73)}$.

\section{Resources}

In addition to the tables found in this paper, further reading on conditioning and animal learning can be found in the journals Applied Animal Behaviour Science, The Journal of the Experimental Analysis of Behavior, Zoo Biology, and Behavioral Processes. Applied Animal Behaviour Science publishes original research in addition to review articles on subjects such as learning with relation to animal husbandry ${ }^{(1)}$, animal psychology and health ${ }^{(18,74)}$, and the use of operant conditioning in agricultural and farm animals ${ }^{(75)}$. The Journal of the Experimental Analysis of Behavior focus on research on learning and although the studies are primarily on rats and pigeons, the principles can be applied to a wide range of species. Furthermore, this journal also features studies on environmental enrichment devices such as feeders for sheep ${ }^{(76)}$ and chickens ${ }^{(77)}$. Zoo Biology is a journal focused on publishing research on animal behavior in captive environments, mostly of exotic species in zoos. Although the researcher is focused on wild captive animals, the studies are applicable to animal behavior in a much broader context and can be used in the management of domestic species in agricultural environments, especially the research on the use of positive reinforcement with training large animals to exhibit safe and desirable behavior in veterinary and husbandry conditions ${ }^{(78,79)}$.

\section{Discussion}

One of the goals of this article is to make farmers and researchers aware that farm animals are highly intelligent, social animals. Typically, the term intelligence has only been applied to such domesticated animals as the family dog and cat, and non-human primates. The research we report here demonstrates that farm animals are also highly intelligent and should not be considered "lessor" animals. As such there is an ethical responsibility to treat these animals with respect and to incorporate strategies that reduce stress and improve animal welfare in agriculture. It is important, therefore, to take into careful consideration the unique behavioral adaptations and requirements of each species when working alongside them in this context.

Classical and operant conditioning can be used by any number of individuals working in and around animals in Brazil. With a greater understanding of learning theory and a thorough understanding of the species with which an individual is working, individuals can create safer environments for both animals and humans. Professionals in veterinary science and workers in agriculture especially need to be aware of the unique needs and behaviors of the species with which they work. A greater understanding of basic behavioral needs and reward values (what each species finds rewarding) can lead to developing associations and positive reinforcement techniques that promote greater welfare for both human and animal under a variety of circumstances.

We would like to note that most of the experiments reported in this paper use control equipment that cost thousands of dollars. To reduce this cost, our laboratory has adapted a microcontroller to manage a wide variety of behavioral experiments. The Propeller Experiment Controller (PEC) is based on the Parallax Propeller microcontroller and costs less than $\$ 100.00$, is applicable to both laboratory and field experiments, is easily adapted to work with a wide range of species, and is no larger than the palm of your hand. The PEC records behavioral and environmental variables by interfacing with a variety of sensors costing dollars rather than hundreds of dollars. A range of programs are available at no cost as free, open-source software, and data files can be viewed in Microsoft Excel. Although we have not done so, the PEC can easily be attached to any farm animal and the data transferred back to the laboratory. Information about the PEC can be found in Innovative Teaching ${ }^{(80)}$.

Much of the research on farm animals cited in this review was conducted within a framework of what is known as "Comparative Psychology"(81). Comparative psychology focuses on exploring the similarities and differences in behavior and is not widely known in Brazil. We believe that such a course 
would be useful for Brazilian veterinary students, zoo-technology students, and even undergraduate students in various programs of study such as psychology ${ }^{(82,83)}$.

In closing, we would like to offer our assistance to anyone who would like to implement a behavioral program with farm animals and/or develop a course in comparative psychology.

\section{References}

1. Wechsler B, Lea SEG. Adaptation by learning: Its significance for farm animal husbandry. Appl Anim Behav Sci. 2007;108:197-214.

2. Tarou LR, Bashaw MJ. Maximizing the effectiveness of environmental enrichment: Suggestions from the experimental analysis of behavior. Appl Anim Behav Sci. 2007;102:189-204.

3. Mignon-Grasteau S, Boissy A, Bouix J, Faure JM, Fisher AD, Hinch GN, et al. Genetics of adaptation and domestication in livestock. Livest Prod Sci. 2005;93(1):3-14.

4. Greenberg G, Haraway M M. Comparative psychology: A handbook. New York: Garland. 1998.

5. Zimbardo PG. Psychology and Life. 13 ${ }^{\text {th }}$ ed. New York: Harper Collins; 1992.

6. Thompson RF, Spencer WA. A model phenomenon for the study of neuronal substrates of behavior. Psychol Rev. 1966;73:16-43.

7. Abramson CI. A Primer of Invertebrate Learning. Washington, DC: American Psychological Association; 1994.

8. Razran G. Mind in Evolution: An East-West Synthesis of Learned Behavior and Cognition. Boston: Houghton Mifflin; 1971.

9. Honig WK, Staddon WK. Handbook of operant behavior. New Jersey: Prentice-Hall: Englewood Cliffs; 1977.

10. Shepherdson DJ. Tracing the Path of Environmental Enrichment in Zoos. In D.J. Sheperdson, J.D Mellen, M. Hutchins (Eds.) Second Nature: Environmental Enrichment for Captive Animals. Washington, DC: Smithsonian Institution Press; 1998. 1-12 p.

11. Dallaire A. Stress and behavior in domestic animals: Temperament as a predisposing factor to stereotypies. Ann NY Acad Sci [Internet]. 1993 [cited 2014 Feb 5]; Available from: http://onlinelibrary.wiley.com/ doi/10.1111/j.1749-6632.1993.tb49940.x/abstract

12. Malamed R, Berger J, Bain MJ, Kass P, Spier SJ. Retrospective evaluation of crib-biting and windsucking behaviours and owner-perceived behavioural traits as risk factors for colic in horses. Equine Vet $\mathrm{J}$. 2010;42(8):686-92.

13. Sarrafchi A, Blokhuis HJ. Equine stereotypic behaviors: Causation, occurrence, and prevention. J Vet Behav Clin Appl Res [Internet]. Elsevier Ltd; 2013 Sep [cited 2014 Feb 4];8(5):386-94. Available from: http:// www.sciencedirect.com/science/article/pii/S1558787813001226

14. Mason G, Clubb R, Lathan N, Vickery S. Why and how should we use environmental enrichment to tackle stereotypic behavior. Appl Anim Behav Sci. 2007;102:163-188.

15. Lagadic H, \& Faure JM. Operant conditioning and use of space by caged laying hens. Behav Process. 1988;16:43-56. 
16. Smith C, Johnson J. The Chicken Challenge: What Contemporary Studies of Fowl Mean for Science and Ethics. Between the Species [Internet]. 2012;15(1):75-102. Available from: http://digitalcommons.calpoly. edu/bts/nhttp://search.ebscohost.com/login.aspx?direct=true\&profile=ehost\&scope=site\&authtype=crawler\&jrnl=19458487\&AN=82261635\&h=qvosVxoKi6blocqaI8mSBVd23NX3tMcjCH3Tj9IxlNdL5pOn2F8NIxEmo2rMxCn3NOkcVIzWTGZAaDUHUb7cuQ==\&crl=c

17. Zimmerman PH, Koene P. The effect of frustrative nonreward on vocalusations and behavior in the laying hen, Gallus gallus domesticus. Behav Process. 1998;44:73-79.

18. Lane H. Operant control of vocalizing in the chicken. J Exp Anal Behav. 1961;4:171-177.

19. Watanabe S. How animal psychology contributes to animal welfare. Appl Anim Behav Sci [Internet]. 2007 Sep [cited 2014 Jan 22];106(4):193-202. Available from: http://linkinghub.elsevier.com/retrieve/pii/ $\underline{\mathrm{S} 0168159107000305}$

20. Smith CL, Johnson J. The Chicken Challenge: What Contemporary Studies of Fowl Mean for Science and Ethics. Between the Species. 2012;15:75-94.

21. Smith CL, Zielinski SL. Brainy bird. Scientific American. 2014;310:60-65

22. Dabrowska B, Harmata W, Lenkiewicz Z, Schiffer Z, Wojtusiak RJ. Colour perception in cows. Behav Process. 1981;6:1-10.

23. Foster TM, Temple T, Robertson B, Nair V, Poling A. Concurrent-schedule performance in dairy cows: Persistent undermatching. J Exp Anal Behav. 1996;65;57-80.

24. Matthews LR, Temple W. Concurrent schedule assessment of food preference in cows. J Exp Anal of Behav. 1979;32:245-254.

25. Pajor EA, Rushen J, de Passill AMB. Aversion learning techniques to evaluate dairy cattle handling practices. Appl Anim Behav Sci. 2000;69:89-102.

26. Rybarczyl P, Koba Y, Rushen J, Tanid H, de Passillé AM. Can cows discriminate people by their faces? Appl Anim Behav Sci. 2001;74:175 189.

27. Arnold NA, Ng KT, Jongman EC, Hemsworth PH. Avoidance of tape-recorded milking facility noise by dairy heifers in a Y maze choice task. Appl Anim Behav Sci. 2008;109:201-210.

28. Lee C, Henshall JM, Wark TJ, Crossman CC, Reed MT, Brewer HG, O'Grady J, Fisher AD. Associative learning by cattle to enable effective and ethical virtual fences. Appl Anim Behav Sci. 2009;119:15-22.

29. Mader TL, Griffin D. Management of Cattle Exposed to Adverse Environmental Conditions. Veterinary Clinics of North America - Food Animal Practice. 2015.

30. Krawczel P, Grant R. Effects of Cow Comfort on Milk Quality, Productivity and Behavior. NMC Annual Meeting Proceedings. 2009. p. 15-24

31. Scott VE, Kerrisk KL, Thomson PC, Lyons NA, Garcia SC. Voluntary cow traffic and behaviour in the premilking yard of a pasture-based automatic milking system with a feed supplementation regime. Livest Sci [Internet]. Elsevier; 2015;171:52-63. Available from: http://dx.doi.org/10.1016/j.livsci.2014.11.002

32. Lindahl C, Pinzke S, Herlin A, Keeling LJ. Human-animal interactions and safety during dairy cattle handling - Comparing moving cows to milking and hoof trimming. Am Dairy Sci Assoc. 2016;(99):2131-41.

33. Pérez-Torres L, Orihuela A, Corro M, Rubio I, Alonso MA, Galina CS. Effects of separation time on behavioral and physiological characteristics of Brahman cows and their calves. Appl Anim Behav Sci 
[Internet]. Elsevier B.V.; 2016;179:17-22. Available from: http://linkinghub.elsevier.com/retrieve/pii/ S0168159116300703

34. Hanggi EB. Discrimination learning based in relative size concepts in horses (Equus caballus). Appl Anim Behav Sci. 2003;83:201-213.

35. Dougherty DM, Lewis P. Stimulus generalization, discrimination learning, and peak shift in horses. J Exp Anal Behav. 1991;56:97-104.

36. Dougherty DM, Lewis P. Matching by horses on several concurrent variable-interval schedules. Behav Process. 1992;26:69-76.

37. Dougherty DM, Lewis P. Generalization of a tactile stimulus in horses. J Exp Anal Behav. 1993;59: 521528.

38. Myers RD, Mesker DC. Operant responding in a horse under several schedules of reinforcement. J Exp Anal of Behav. 1960;3:161-164.

39. Miyashita Y, Nakajima S, Imada H. Differential outcome effect in the horse. J Exp Anal of Behav. 2000;74:245-253.

40. Craig DPA, Varnon CA, Pollock KL, Abramson CI. An assessment of horse (Equus ferus caballus) responding on fixed interval schedules of reinforcement: An individual analysis. Behav Processes [Internet]. Elsevier B.V.; 2015;120:1-13. Available from: http://linkinghub.elsevier.com/retrieve/pii/ S0376635715300243

41. Martin TI, Zentall TR, Lawrence L. Simple discrimination reversals in the domestic horse (Equus caballus): Effect of discriminative stimulus modality on learning to learn. Appl Anim Behav Sci. 2006;101:328-338.

42. Gabor V, Gerken M. Cognitive testing in horses using a computer based apparatus. Appl Anim Behav Sci. 2012;139:242-250.

43. Ferguson DL, Rosales-Ruiz J. Loading the problem loader: The effects of target training and shaping on trailer-loading behavior of horses. J App Behav Anal. 2001;34:409-424.

44. McGreevy PD. The advent of equitation science. Vet J [Internet]. 2007 Nov [cited 2014 Mar 4];174(3):492-500. Available from: http://www.ncbi.nlm.nih.gov/pubmed/17157542

45. Jones B, McGreevy PD. Ethical equitation: Applying a cost-benefit approach. J Vet Behav Clin Appl Res [Internet]. Elsevier Inc; 2010 Jul [cited 2014 Feb 9];5(4):196-202. Available from: http://linkinghub.elsevier. com/retrieve/pii/S1558787810000614

46. Goodwin D. The importance of ethology in understanding the behaviour of the horse. Equine Vet J Suppl [Internet]. 1999 Apr;28(28):15-9. Available from: http://www.ncbi.nlm.nih.gov/pubmed/11314229

47. Hanggi E. The thinking horse: cognition and perception reviewed. Am Assoc Equine Pract 51st ... [Internet]. 2005 [cited 2014 Feb 8]; Available from: http://www.hannoveranare.se/dokument/hanggithinkinghorse.pdf

48. Wenzel BM, Baldwin BA, Tschirgi RD. Operant conditioning of goats. J Exp Anal of Behav. 1964;7:263266.

49. Foster TM, Matthews LR, Temple W, Poling A. Concurrent schedule performance in domestic goats: persistent undermatching. Behav Process. 1997;40:231-237. 
50. Langbein J, Siebert K, Nurnberg G. On the use of automated learning device by group-housed dwarf goats: Do goats seek cognitive challenges? Appl Anim Behav Sci. 2009;120:150-158.

51. de Ameida MB, Schild AL, Brasil NDA, Quevedo PS, Fiss L, Pfister JA, Riet-Correa F. Conditioned aversion in sheep induced by Baccharis coridifolia. Appl Anim Behav Sci. 2009;117:197-200.

52. Manuelian CL, Albanell E, Salama AAK, Caja G. Conditioned aversion to olive tree leaves (Olea europaea L.) in goats and sheep. Appl Anim Behav Sci. 2010;128:45-49.

53. de Oliveira D, Paranhos da Costa MJR, Zupan M, Rehn T, Keeling LJ. Early human handling in nonweaned piglets: Effects on behaviour and body weight. Appl Anim Behav Sci. 2015;164:56-63.

54. Brajon S, Laforest J-P, Schmitt O, Devillers N. A preliminary study of the effects of individual response to challenge tests and stress induced by humans on learning performance of weaned piglets (Sus scrofa). Behav Processes [Internet]. Elsevier B.V.; 2016; Available from: http://inkinghub.elsevier.com/retrieve/pii/ $\underline{\mathrm{S} 0376635716301218}$

55. van Eck LM, Antonides A, Nordquist RE, van der Staay FJ. Testing post-weaning food motivation in low and normal birth weight pigs in a runway and operant conditioning task. Appl Anim Behav Sci [Internet]. Elsevier B.V.; 2016; Available from: http://linkinghub.elsevier.com/retrieve/pii/S016815911630137X

56. Cornale P, Macchi E, Miretti S, Renna M, Lussiana C, Perona G, et al. Effects of stocking density and environmental enrichment on behavior and fecal corticosteroid levels of pigs under commercial farm conditions. J Vet Behav Clin Appl Res [Internet]. Elsevier Inc; 2015;10(6):569-76. Available from: http:// dx.doi.org/10.1016/j.jveb.2015.05.002

57. Thys S, Mwape KE, Lefèvre P, Dorny P, Phiri AM, Marcotty T, et al. Why pigs are free-roaming: Communities' perceptions, knowledge and practices regarding pig management and taeniosis/cysticercosis in a Taenia solium endemic rural area in Eastern Zambia. Vet Parasitol [Internet]. Elsevier B.V.; 2016; Available from: http://linkinghub.elsevier.com/retrieve/pii/S0304401716301947

58. Albiach-Serrano A, Bräuer J, Cacchione T, Zickert N, Amici F. The effect of domestication and ontogeny in swine cognition (Sus scrofa scrofa and S. s. domestica). Appl Anim Behav Sci [Internet]. Elsevier B.V.; 2012;141(1-2):25-35. Available from: http://dx.doi.org/10.1016/j.applanim.2012.07.005

59. Scheffler K, Stamer E, Traulsen I, Krieter J. Genetic analysis of the individual pig behaviour in backtests and human approach tests. Appl Anim Behav Sci [Internet]. Elsevier B.V.; 2014;160(1):38-45. Available from: http://dx.doi.org/10.1016/j.applanim.2014.08.010

60. Figueroa J, Sola-Oriol D, Manteca X, Perez JF, Dwyer DM. Anhedonia in pigs? Effects of social stress and restraint stress on sucrose preference. Physiol Behav [Internet]. Elsevier Inc.; 2015;151:509-15. Available from: http://dx.doi.org/10.1016/j.physbeh.2015.08.027

61. Büttner K, Scheffler K, Czycholl I, Krieter J. Network characteristics and development of social structure of agonistic behaviour in pigs across three repeated rehousing and mixing events. Appl Anim Behav Sci [Internet]. Elsevier B.V.; 2015;168:24-30. Available from: http://dx.doi.org/10.1016/j.applanim.2015.04.017

62. Gieling ET, Musschenga MA, Nordquist RE, van der Staay FJ. Juvenile pigs use simple geometric 2D shapes but not portrait photographs of conspecifics as visual discriminative stimuli. Appl Anim Behav Sci [Internet]. Elsevier B.V.; 2012;142(3-4):142-53. Available from: http://dx.doi.org/10.1016/j. applanim.2012.10.018

63. Oostindjer M, Bolhuis JE, Mendl M, Held S, van den Brand H, Kemp B. Learning how to eat like a pig: Effectiveness of mechanisms for vertical social learning in piglets. Anim Behav [Internet]. Elsevier Ltd; 2011;82(3):503-11. Available from: http://dx.doi.org/10.1016/j.anbehav.2011.05.031 
64. Oostindjer M, Kemp B, van den Brand H, Bolhuis JE. Facilitating "learning from mom how to eat like a pig" to improve welfare of piglets around weaning. Appl Anim Behav Sci [Internet]. Elsevier B.V.; 2014;160(1):19-30. Available from: http://dx.doi.org/10.1016/j.applanim.2014.09.006

65. Carreras R, Mainau E, Rodriguez P, Llonch P, Dalmau A, Manteca X, et al. Cognitive bias in pigs: Individual classification and consistency over time. J Vet Behav Clin Appl Res. 2015;10(6):577-81.

66. Jensen MB, Herskin MS, Forkman B, Pedersen LJ. Effect of increasing amounts of straw on pigs' explorative behaviour. Appl Anim Behav Sci [Internet]. Elsevier B.V.; 2015;171:58-63. Available from: http://dx.doi.org/10.1016/j.applanim.2015.08.035

67. Pedersen LJ, Herskin MS, Forkman B, Halekoh U, Kristensen KM, Jensen MB. How much is enough? The amount of straw necessary to satisfy pigs' need to perform exploratory behaviour. Appl Anim Behav Sci [Internet]. Elsevier B.V.; 2014;160(1):46-55. Available from: http://dx.doi.org/10.1016/j. applanim.2014.08.008

68. Broom DM, Sena H, Moynihan KL. Pigs learn what a mirror image represents and use it to obtain information. Anim Behav [Internet]. Elsevier Ltd; 2009;78(5):1037-41. Available from: http://dx.doi. org/10.1016/j.anbehav.2009.07.027

69. Scollo A, Gottardo F, Contiero B, Edwards SA. Does stocking density modify affective state in pigs as assessed by cognitive bias, behavioural and physiological parameters? Appl Anim Behav Sci [Internet]. Elsevier B.V.; 2014;153:26-35. Available from: http://dx.doi.org/10.1016/j.applanim.2014.01.006

70. Fijn L, Antonides A, Aalderink D, Nordquist RE, van der Staay FJ. Does litter size affect emotionality, spatial learning and memory in piglets? Appl Anim Behav Sci [Internet]. Elsevier B.V.; 2016;178:23-31. Available from: http://dx.doi.org/10.1016/j.applanim.2016.02.011

71. Zebunke M, Repsilber D, Nurnberg G, Wittenburg D, Puppe B. The backtest in pigs revisited - An analysis of intra-situational behaviour. Appl Anim Behav Sci [Internet]. Elsevier B.V.; 2015;169:17-25. Available from: http://dx.doi.org/10.1016/j.applanim.2015.05.002

72. Maselyne J, Saeys W, Van Nuffel A. Review: Quantifying animal feeding behaviour with a focus on pigs. Physiol Behav [Internet]. Elsevier Inc.; 2015;138:37-51. Available from: http://dx.doi.org/10.1016/j. physbeh.2014.09.012

73. Leliveld LMC, Düpjan S, Tuchscherer A, Puppe B. Behavioural and physiological measures indicate subtle variations in the emotional valence of young pigs. Physiol Behav [Internet]. Elsevier Inc.; 2016;157:116-24. Available from: http://dx.doi.org/10.1016/j.physbeh.2016.02.002

74. Dawkins MS. Through animal eyes: What behaviour tells us. Appl Anim Behav Sci. 2006;100:4-10.

75. Kilgour R, Foster TM, Temple W, Matthews LR, Bremner KJ. Operant technology applied to solving farm animal problems, An assessment. Appl Anim Behav Sci. 1991;30:141-166.

76. Sandler BE, Van Gelder GA, Karas GG, Buck WB. An operant feeding device for sheep. J Exp Anal of Behav. 1971;15:95-96.

77. Berkhoudt $\mathrm{H}$, van der Reijden D, Meijmans M. An automatic pellet dispensor for precise control of feeding topography in granivorous birds. J Exp Anal Behav. 1987;48:435-438.

78. Laule GE, Thurston RH, Alford PL, Bloomsmith MA. Training to reliably obtain blood and urine samples from a diabetic chimpanzee (Pan troglodytes). Zoo Biol. 1996;15:587-591.

79. Broder JM, MacFadden AJ, Cosens LM, Rosenstein DS, Harrison TM. Use of positive reinforcement conditioning to monitor pregnancy in an unanesthetized snow leopard (Uncia uncia) via transabdominal 
ultrasound. Zoo Biol. 2008;27:78-85.

80. Varnon CA, Abramson CI. The propeller experiment controller: Low-cost automation for classroom experiments in learning and behavior. Innovative Teaching [Internet]. 2013;2(2). doi: 10.2466/07.08.IT.2.2

81. Abramson CI. Comparative Psychology. In: The World Book Encyclopedia. Chicago, IL: World Book Publishing; 2006. 902a-902b p.

82. Abramson CI, Hilker AC, Becker B, Barber KR, Miskovsky C. Cost-Effective Laboratory Exercises to Teach Principles in the Comparative Analysis of Behavior. Journal of Behavioral and Neuroscience Research. 2011;9:7-15.

83. Abramson CI. A crisis in comparative psychology: Where have all the undergraduates gone? Frontiers in Psychology. 2015;6:1500. doi: 10.3389/fpsyg.2015.01500 